\title{
THE DYNAMICS OF A LONG-STAY MENTAL HOSPITAL POPULATION
}

\author{
K. W. CROSS, Ph.D. \\ Department of Social Medicine, University of Birmingham \\ CHRISTINE HASSALL, M.Sc. \\ Department of Psychiatry, University of Birmingham
}

AND

A. M. SPENCER, B.Sc., M.B., Ch.B., D.P.M.

Powick Hospital, Nr Worcester

THE census of all patients in psychiatric hospitals and units in England and Wales (Brooke, 1967) showed that the rundown of this inpatient population, as forecast by Tooth and Brooke (1961), was being maintained in 1963. Since then other studies (Lancet leading article, 1969) have confirmed this continuing trend, although the rate of decline obviously varies from area to area. In the Birmingham Region, for example, the number of patients in residence per 10,000 population of the region was 21 at the end of 1968 as compared to 28 per 10,000 population at the end of 1958 .

These reductions are mainly due to the falling numbers of long-stay patients (those continuously in residence for at least two years), and for any such long-stay population it is important to study separately (1) the changing pattern of a standing population selected at a given time; and (2) the extent to which new patients are accumulating.

In a previous paper (Hassall, Spencer, and Cross, 1965) the authors considered in some detail the composition of the inpatient populations of Powick Hospital at the end of each of the years 1952, 1957, and 1960. These patients were followed up until the end of 1962 and annual rates of discharge and death for the three populations were compared.

The purpose of the present contribution is to study the subsequent experience of patients admitted to the hospital over the 10 years 1956-65 and to estimate the annual rates of accumulation of 'new' long-stay patients and their contribution to bed occupancy.

By combining results from the two enquiries, forecasts of long-stay hospital populations can be made. Important differences exist between localities in respect of the needs for inpatient psychiatric care, and it is important to conduct local studies which take account of as much relevant data as possible regarding the changing patterns of admission and discharge of patients.

\section{Material ANd Method}

Powick Hospital serves both urban and rural districts in Worcestershire. The population of the catchment area was in the region of 300,000 until 1959 when adjustments to the area resulted in a reduction to 260,000. The hospital adopted a policy of unrestricted admission in 1950, so that general practitioners arrange for the admission of a patient without first having to obtain a psychiatric assessment.

A record card was completed for each patient admitted to Powick Hospital from the catchment area during the years 1956-60 inclusive. Each patient was then followed up until the end of 1962, details being recorded of any admission, departure or death during the intervening period. In addition, patients admitted during the years 1961-65 inclusive were followed up until the end of 1967, although recording was limited to identifying those patients becoming long stay and their subsequent experience.

\section{Admission Rates}

\section{REsults}

As was true of most mental hospitals, the annual admission rate per 1,000 population increased over this decade and most markedly during the latter half; the 1965 admission rate of 375 per 1,000 was almost double the 1956 rate (196).

Age and Sex Distributions of Patients Admitted

The age and sex distributions of patients admitted over the two five-year periods are given in Table I. 
TABLE I

AGE AND SEX DISTRIBUTIONS OF PATIENTS ADMITTED FROM CATCHMENT AREA

\begin{tabular}{|c|c|c|c|c|c|}
\hline \multirow{2}{*}{ Period } & \multirow{2}{*}{ Sex } & \multicolumn{3}{|c|}{ Age (yr) } & \multirow{2}{*}{$\begin{array}{l}\text { Per cent } \\
65 \text { and } \\
\text { over }\end{array}$} \\
\hline & & Under 65 & $\begin{array}{l}65 \text { and } \\
\text { over }\end{array}$ & Total & \\
\hline $1956-60$ & $\begin{array}{l}\text { Male } \\
\text { Female } \\
\text { Total }\end{array}$ & $\begin{array}{l}1148 \\
1333 \\
2481\end{array}$ & $\begin{array}{l}202 \\
455 \\
657\end{array}$ & $\begin{array}{l}1350 \\
1788 \\
3138\end{array}$ & $\begin{array}{l}15 \cdot 0 \\
25 \cdot 4 \\
20 \cdot 9\end{array}$ \\
\hline $1961-65$ & $\begin{array}{l}\text { Male } \\
\text { Female } \\
\text { Total }\end{array}$ & $\begin{array}{l}1686 \\
2166 \\
3852\end{array}$ & $\begin{array}{r}339 \\
676 \\
1015\end{array}$ & $\begin{array}{l}2025 \\
2842 \\
4867\end{array}$ & $\begin{array}{l}16 \cdot 7 \\
23 \cdot 8 \\
20 \cdot 9\end{array}$ \\
\hline
\end{tabular}

Of all male admissions during $1956-60,15 \%$ were 65 years of age or over, and a quarter of all women admitted during this period were in this age group; more than twice as many elderly women as men were admitted. There was a smaller excess of female patients under 65 years of age, the ratio of female to male admissions being $1 \cdot 2: 1$.

The numbers of elderly men and women admitted were much greater during the second period; $16.7 \%$ of the men and $23.8 \%$ of the women were 65 years of age or over. The proportionate contribution of elderly men to all admissions (males and females) increased slightly from $6.4 \%$ to $7.0 \%$, whereas the proportion of elderly women decreased slightly from $14.5 \%$ to $13.9 \%$.

\section{Occurrence of New Long-Stay Patients}

We now consider the extent to which patients entering hospital in a given year subsequently become long-stay, i.e., remain in hospital continuously for two years or longer. Table II (a) gives for each sex and age-group specified the numbers and pro-

TABLE II

NUMBERS AND PROPORTIONS OF ADMISSIONS BECOMING LONG-STAY BY YEAR OF ADMISSION, SEX AND AGE GROUP (a) 1956 to 1960 COHORTS

\begin{tabular}{|c|c|c|c|c|c|c|c|c|c|}
\hline \multirow{2}{*}{$\begin{array}{c}\text { Year } \\
\text { of } \\
\text { Admission }\end{array}$} & \multicolumn{3}{|c|}{ Less than 65 Years } & \multicolumn{3}{|c|}{65 Years and Over } & \multicolumn{2}{|r|}{ All Ages } & \\
\hline & $\begin{array}{c}\text { No. of } \\
\text { Admissions }\end{array}$ & $\begin{array}{c}\text { No. of } \\
\text { Long-stay } \\
\text { Cases }\end{array}$ & $\%$ & $\begin{array}{c}\text { No. of } \\
\text { Admissions }\end{array}$ & $\begin{array}{l}\text { No. of } \\
\text { Long-stay } \\
\text { Cases }\end{array}$ & $\%$ & $\begin{array}{c}\text { No. of } \\
\text { Admissions }\end{array}$ & $\begin{array}{l}\text { No. of } \\
\text { Long-stay } \\
\text { Cases }\end{array}$ & $\%$ \\
\hline $\begin{array}{r}\text { Males } \\
1956 \\
1957 \\
1958 \\
1959 \\
1960\end{array}$ & $\begin{array}{l}229 \\
219 \\
256 \\
208 \\
236\end{array}$ & $\begin{array}{l}12 \\
12 \\
22 \\
15 \\
15\end{array}$ & $\begin{array}{l}5 \cdot 2 \\
5 \cdot 5 \\
8 \cdot 6 \\
7 \cdot 2 \\
6 \cdot 4\end{array}$ & $\begin{array}{l}32 \\
37 \\
37 \\
47 \\
49\end{array}$ & $\begin{array}{l}5 \\
1 \\
3 \\
7 \\
4\end{array}$ & $\begin{array}{r}15 \cdot 6 \\
2 \cdot 7 \\
8 \cdot 1 \\
14 \cdot 9 \\
8 \cdot 2\end{array}$ & $\begin{array}{l}261 \\
256 \\
293 \\
255 \\
285\end{array}$ & $\begin{array}{l}17 \\
13 \\
25 \\
22 \\
19\end{array}$ & $\begin{array}{l}6 \cdot 5 \\
5 \cdot 1 \\
8 \cdot 5 \\
8 \cdot 6 \\
6 \cdot 7\end{array}$ \\
\hline All years & 1,148 & 76 & $6 \cdot 6$ & 202 & 20 & $9 \cdot 9$ & 1,350 & 96 & $7 \cdot 1$ \\
\hline $\begin{array}{r}\text { Females } \\
1956 \\
1957 \\
1958 \\
1959 \\
1960\end{array}$ & $\begin{array}{l}250 \\
249 \\
261 \\
270 \\
303\end{array}$ & $\begin{array}{r}10 \\
9 \\
17 \\
20 \\
13\end{array}$ & $\begin{array}{l}4 \cdot 0 \\
3 \cdot 6 \\
6 \cdot 5 \\
7 \cdot 4 \\
4 \cdot 3\end{array}$ & $\begin{array}{r}73 \\
90 \\
100 \\
79 \\
113\end{array}$ & $\begin{array}{r}7 \\
11 \\
16 \\
9 \\
15\end{array}$ & $\begin{array}{r}9 \cdot 6 \\
12 \cdot 2 \\
16 \cdot 0 \\
11 \cdot 4 \\
13 \cdot 3\end{array}$ & $\begin{array}{l}323 \\
339 \\
361 \\
349 \\
416\end{array}$ & $\begin{array}{l}17 \\
20 \\
33 \\
29 \\
28\end{array}$ & $\begin{array}{l}5 \cdot 3 \\
5 \cdot 9 \\
9 \cdot 1 \\
8 \cdot 3 \\
6 \cdot 7\end{array}$ \\
\hline All years & 1,333 & 69 & $5 \cdot 2$ & 455 & 58 & $12 \cdot 7$ & 1,788 & 127 & $7 \cdot 1$ \\
\hline
\end{tabular}

(b) 1961 TO 1965 COHORTS

\begin{tabular}{|c|c|c|c|c|c|c|c|c|c|}
\hline \multirow[b]{2}{*}{$\begin{array}{c}\text { Year } \\
\text { of } \\
\text { Admission }\end{array}$} & \multicolumn{3}{|c|}{ Less than 65 Years } & \multicolumn{3}{|c|}{65 Years and Over } & \multicolumn{3}{|c|}{ All Ages } \\
\hline & $\begin{array}{c}\text { No. of } \\
\text { Admissions }\end{array}$ & $\begin{array}{l}\text { No. of } \\
\text { Long-stay } \\
\text { Cases }\end{array}$ & $\%$ & $\begin{array}{c}\text { No. of } \\
\text { Admissions }\end{array}$ & $\begin{array}{l}\text { No. of } \\
\text { Long-stay } \\
\text { Cases }\end{array}$ & $\%$ & $\begin{array}{c}\text { No. of } \\
\text { Admissions }\end{array}$ & $\begin{array}{l}\text { No. of } \\
\text { Long-stay } \\
\text { Cases }\end{array}$ & $\%$ \\
\hline $\begin{array}{rr}\text { Males } & \\
1961 \\
1962 \\
1963 \\
1964 \\
1965\end{array}$ & $\begin{array}{l}298 \\
333 \\
313 \\
362 \\
380 \\
\end{array}$ & $\begin{array}{l}15 \\
19 \\
12 \\
11 \\
14\end{array}$ & $\begin{array}{l}5 \cdot 0 \\
5 \cdot 7 \\
3 \cdot 8 \\
3 \cdot 0 \\
3 \cdot 7\end{array}$ & $\begin{array}{l}57 \\
65 \\
79 \\
67 \\
71\end{array}$ & $\begin{array}{l}4 \\
5 \\
6 \\
7 \\
6\end{array}$ & $\begin{array}{r}7 \cdot 0 \\
7 \cdot 7 \\
7 \cdot 6 \\
10 \cdot 4 \\
8 \cdot 4\end{array}$ & $\begin{array}{l}355 \\
398 \\
392 \\
429 \\
451\end{array}$ & $\begin{array}{l}19 \\
24 \\
18 \\
18 \\
20\end{array}$ & $\begin{array}{l}5 \cdot 4 \\
6 \cdot 0 \\
4 \cdot 6 \\
4 \cdot 2 \\
4 \cdot 4\end{array}$ \\
\hline All years & 1686 & 71 & $4 \cdot 2$ & 339 & 28 & $8 \cdot 3$ & 2025 & 99 & $4 \cdot 9$ \\
\hline $\begin{array}{r}\text { Females } \\
1961 \\
1962 \\
1963 \\
1964 \\
1965\end{array}$ & $\begin{array}{l}354 \\
406 \\
445 \\
452 \\
509\end{array}$ & $\begin{array}{l}14 \\
19 \\
16 \\
13 \\
13\end{array}$ & $\begin{array}{l}4 \cdot 0 \\
4 \cdot 7 \\
3 \cdot 6 \\
2 \cdot 9 \\
2 \cdot 6\end{array}$ & $\begin{array}{r}99 \\
130 \\
141 \\
166 \\
140\end{array}$ & $\begin{array}{l}10 \\
19 \\
12 \\
12 \\
12\end{array}$ & $\begin{array}{r}10 \cdot 1 \\
14 \cdot 6 \\
8 \cdot 5 \\
7 \cdot 2 \\
8 \cdot 6\end{array}$ & $\begin{array}{l}453 \\
536 \\
586 \\
618 \\
649\end{array}$ & $\begin{array}{l}24 \\
38 \\
28 \\
25 \\
25\end{array}$ & $\begin{array}{l}5 \cdot 3 \\
7 \cdot 1 \\
4 \cdot 8 \\
4 \cdot 0 \\
3 \cdot 9\end{array}$ \\
\hline All years & 2166 & 75 & $3 \cdot 5$ & 676 & 65 & $9 \cdot 6$ & 2842 & 140 & $4 \cdot 9$ \\
\hline
\end{tabular}


portions of such patients referable to each cohort of admissions during the first five-year period.

For men of all ages the annual proportion remaining continuously in residence for at least two years varied between $5.1 \%$ and $8.6 \%$, and the corresponding range for women was $5.3 \%$ to $9 \cdot 1 \%$. For both men and women the values relating to the 1958 and 1959 cohorts were somewhat higher than those for other years. No trends are evident over the five years either in the numbers or the proportions of patients becoming long-stay cases per annum.

Combining the two sexes, the mean annual number of new long-stay patients was 45 , and relating this to the 1959 catchment area population of the hospital, the rate obtained is $15 \cdot 3$ per 100,000 population. The comparable 1959 figure estimated by Brooke (1962) for all hospitals in England and Wales was $16 \cdot 6$.

On the average, 15 males and 14 females under 65 years of age became long-stay patients per annum. For the older age-group, the female mean annual value (12) is three times as great as the male (4). The number of men aged 65 and over becoming long-stay in any one year was very small, and consequently there is a sizeable variation from year to year about the mean.

The numbers and proportions of patients becoming long-stay during the period 1961-65 are recorded in Table II (b) for each sex and age-group. The annual number of admissions from the catchment area increased dramatically over these five years. The number of male patients of all ages becoming long-stay was almost the same as that for the earlier period, but the proportion was less. More female patients became long-stay during the later period although the proportion was reduced to $5 \%$ of all admissions.

\section{Build-up of New Long-STAy Populations}

As stated previously, each long-stay patient from those admitted during 1956-60 was followed up until the end of 1962, and whether or not the patient was still in hospital at the end of each year after the year of becoming long-stay was recorded. Similarly, those long-stay patients accruing from the 1961-65 cohorts of admissions were followed up until the end of 1967. By the usual life-table methods we may calculate for these patients becoming long-stay in a year $(x)$ the proportions still in residence at the end of years $(x+1),(x+2), \ldots(x+4)$; the proportion for the last-named interval is based upon the experience of only one annual cohort of admission. These survival proportions $\left(p_{x}+n, n=1\right.$ to 4$)$ are given in Table III for each of the two five-year periods. For both periods, the male and female
TABLE III

PERCENTAGES SURVIVING TO END OF SUBSEQUENT YEARS OF PATIENTS BECOMING LONG-STAY IN YEAR X

\begin{tabular}{c|c|c|c|c}
\hline \multirow{2}{*}{ Year } & \multicolumn{2}{|c|}{ Admitted during 1956-60 } & \multicolumn{2}{c}{ Admitted during 1961-65 } \\
\cline { 2 - 3 } & Males & Females & Males & Females \\
\cline { 1 - 2 } $\mathbf{x}+1$ & 82 & 80 & 70 & 65 \\
$\mathrm{x}+2$ & 58 & 61 & 52 & 53 \\
$\mathrm{x}+3$ & 51 & 49 & 39 & 41 \\
$\mathrm{x}+4$ & 45 & 35 & 39 & 38 \\
\hline
\end{tabular}

proportions were very similar, and the percentages remaining for the later series were less than the corresponding values for the earlier series, except for the female proportion $p_{x+4}$. When the male and female distributions for the earlier period are combined, the proportions conform closely to the geometric sequence defined by $\mathrm{p}_{\mathrm{x}}+\mathrm{n}=100(0 \cdot 8)^{\mathrm{n}}$.

We may now make estimates of the cumulative effect of successive cohorts in generating 'new' long-stay populations, i.e., of patients who became long-stay after the end of 1960 and remained in hospital over subsequent years. The exact numbers of such patients in residence at the end of 1961 and 1962 can, of course, be specified. Forecasts for the years 1963-67 are based on: (1) the actual follow-up results for those who became long-stay patients during the years 1963-67, and (2) estimates of the numbers remaining from those patients who became long-stay in 1961 and 1962. These latter estimates have been calculated by applying the geometric distribution given above.

These results are given in Table IV and suggest that by the end of 1967 the population had almost reached its maximum. From the results given in Tables II and III there is no reason to believe that

TABLE IV

LONG-STAY POPULATIONS GENERATED FROM PATIENTS ADMITTED 1959-1965 INCLUSIVE

\begin{tabular}{c|c|c|c}
\hline Year & Males & Females & Total \\
\cline { 2 - 3 } 1961 & 22 & 29 & 51 \\
1962 & 35 & 52 & 87 \\
1963 & 48 & 65 & 113 \\
1964 & 62 & 88 & 150 \\
1965 & 67 & 90 & 157 \\
1966 & 67 & 89 & 156 \\
1967 & 66 & 95 & 161 \\
\hline
\end{tabular}

either the annual number of long-stay patients accruing, or their survival rates, will increase in future years. It seems likely therefore that, by the end of 1970, the male and female populations generated since 1960 will be of the order of 70 and 100 respectively.

Decline of the 1960 Long-stay Population

Our previous paper (Hassall et al., 1965) gave for 
those patients who had been continuously in residence in Powick Hospital for two years or longer at the end of each year 1952, 1957 and 1960, the proportions remaining at the end of subsequent years up to and including 1962. Over this period the decay distribution for the 1952 long-stay population was approximately linear; $76 \%$ were still in residence after five years and $55 \%$ after 10 years. The proportion of the 1957 population remaining after five years was $68 \%$, the values for male and female patients being almost identical. Assuming a linear decay distribution for this population, the 10 -year survival proportion would be $46 \%$.

The 1960 long-stay population was followed for only two years and the proportion remaining after this period was $83 \%$, the same as the corresponding value for the 1957 population.

It is reasonable to assume, therefore, that about $46 \%$ of the 1960 population of 310 male and 426 female patients will still be in hospital at the end of 1970, i.e., 145 males and 200 females. In other words, about 165 male and 225 female patients will have left the hospital by then. These estimates are more than double the numbers of 'new' long-stay patients who accumulated since 1960 , even allowing for the fact that the latter refer only to admissions from the hospital's catchment area, which account for $95 \%$ of all admissions to the hospital.

\section{Discussion}

It is estimated that from a population of 270,000 a 'new' long-stay population of 170 patients will have accumulated over the 10 years since 1960 . There is evidence (Table IV) that the build-up will have reached a maximum at this level, so that in planning new psychiatric accommodation in this area the provision for long-stay patients would need to be of the order of 0.65 bed per 1,000 population at risk. This compares with the ratio of 0.89 calculated by Tooth and Brooke (1961).

The demand for mental hospital beds is partly determined by the availability of supporting facilities, such as adequate outpatient clinics, day-patient places, sheltered workshops, and, not least of all, psycho-geriatric accommodation. In the past, Powick Hospital has had insufficient funds to provide many day hospital places, and out-patient clinics were scattered over a wide area and were over-crowded. Where a parent hospital serves a widespread rural community, public transport is sometimes poor and the ambulance service often over-extended. For the majority of such hospitals the provision of inpatient units in general hospitals, or of the supporting services mentioned above, may not be possible in the near future.
Extending or improving services does not necessarily mean that the demand for beds will decline. Kessel and Hassall (1970) have shown that, in the Plymouth area, where a day hospital and improved outpatient facilities were made available in 1963, the predicted changes in the pattern of admissions, and of the standing population of the mental hospital serving the area, had not occurred by the end of 1964. However, no one would deny that the patients in the area receive a vastly improved service.

The number of psychiatric units in general hospitals is increasing but they cannot be seen at present as the panacea for all the ills of the mental health service. Supporting facilities often lag behind the development of such units; and for these facilities to operate effectively they need to be backed up by immediately available beds, especially for 'chronic' patients. It seems that there will always be those who are brain damaged, organically deteriorated, senile, and schizophrenic who may be maintained for some time on a day-patient basis but will, in all probability, end their days in hospital.

Beds for long-stay patients seem likely to be needed for many years to come, though in decreasing numbers. Persistent reference to the 'running down' of the large mental hospital leads to reluctance to spend money on such hospitals and adds to the difficulty of recruiting and maintaining adequate staff. Thousands of patients are living out their lives in these hospitals, in many cases with no hope of discharge, and, as recent adverse publicity has shown, with minimal care in overcrowded conditions. Paper plans will not alleviate the distress of these patients who cannot be expected to understand that they must endure unsatisfactory conditions because they are 'a diminishing statistic'.

\section{SUMMARY}

This study at Powick Hospital has shown that the accumulation of 'new' long-stay patients since 1960 has been less than half the reduction due to discharge or death of patients who were long-stay at the end of 1960. In planning new accommodation it is suggested that in the foreseeable future 0.65 bed per 1,000 population will be required for long-stay patients of all ages.

There is no doubt that the standing long-stay population of this hospital is decreasing fairly rapidly. However, there are many regional differences, particularly in the provision of those supporting services which are crucial to the ability to discharge 'chronic' patients and to their well-being if they are to be successfully maintained in the community. 


\section{REFERENCES}

BroOKE, E. M. (1962). Factors affecting the demand for psychiatric beds. Lancet, 2, 1211.

(1967). A census of patients in psychiatric beds, 1963. Min. Hlth Rep. publ. Hlth med. Subject, No. 116. H.M.S.O., London.

Hassall, Christine, Spencer, A. M., and Cross, K. W. (1965). Some changes in the composition of a mental hospital population. Brit. J. Psychiat., 111, 420.

Kessel, N., and Hassall, Christine (1970). Evaluation of the functioning of the Plymouth Nuffield Clinic. Brit. J. Psychiat., in press.

Leading article (1969). By beds alone? Lancet, 2, 35.

Tooth, G. C., and Brooke, E. M. (1961). Trends in the mental hospital population and their effect on future planning. Lancet, 1, 710. 